\title{
Selection and Characterization of Rhizosphere Fungi Producing Siderophore
}

\author{
Eka Wisdawati $^{{ }^{*}}$, Tutik Kuswinanti ${ }^{2}$, Ade Rosmana ${ }^{2}$ and Andi Nasruddin ${ }^{2}$ \\ ${ }^{1}$ Graduate School, Hasanuddin University, Indonesia \\ ${ }^{2}$ Plant Pest and Disease Department, Hasanuddin University, Indonesia \\ *Corresponding author
}

\begin{abstract}
A B S T R A C T
Keywords

Fungi, Iron,

Rhizosphere,

Siderophore

Article Info

Accepted:

04 October 2019

Available Online:

10 November 2019

Iron has low solubility in nature so that the role of siderophore as chelating iron and inhibiting a pathogenic enzyme is needed for plant growth. In this study, we selected and characterized fungi producing siderophore with the aim can be used as biofertilizer and biocontrol. There were 10 fungal isolates in total from rhizosphere which were obtained produced various siderophores. Catechol siderophore emitted was between $5,07 \mu \mathrm{g}^{-1}$ and $14.87 \mu \mathrm{g} \mathrm{l}^{-1}$ while the salicylate siderophore ranged from $3.89 \mu \mathrm{g}{ }^{-1}$ to 7,21 $\mu \mathrm{g} 1^{-1}$. ETR17 which produced the highest rate of catechol siderophore which was $14.87 \mu \mathrm{g} \mathrm{l}^{-1}$ and salicylate siderophore $7.21 \mu \mathrm{g} \mathrm{l}^{-1}$. The isolate was identified and characterized as Aspergillussp
\end{abstract}

\section{Introduction}

Iron is a micronutrient which is highly necessary for almost all organisms because it has the role in enzymatic and metabolism process like respiration and DNA synthesis (Kraemer, 2003; Miethke, 2017). Similarly, plants require iron nutrient for their growth and development. In nature, iron in forms of oxides and hydroxide are abundant but difficult to be absorbed by plants because $\mathrm{Fe}^{3+}$ is less soluble. As a result, they are difficult to be used by organisms. They are different from some microorganisms like bacteria (Arora,
2017; Patil 2014, Chakraborty, 2014), yeast (Ghosh, 2015) and fungi (Ghosh, 2017; Usha, 2013) that can secrete secondary metabolite siderophore with less iron compound (Hussein, 2019; Prema, 2013). Some fungi producing siderophore are Trichoderma harzianum, T. viride, T. asperellum (Ghosh, 2017), Aspergillusniger and A. flavus (Usha, 2013).

Microorganisms release siderophore to scavenge mineral iron by forming dissolved $\mathrm{Fe}^{3+}$ complex through active transport mechanism (Kraemer, 2003). Siderophore 
secreted by microorganisms is the strongest binder of $\mathrm{Fe}^{3+}$ (Raymond, 2003) and can act as an iron chelator (Prema, 2013; Kraemer, 2003), absorber, and solvent (Miethke, 2007).

Besides that, siderophore also has potential to control phytopathogenic fungi and bacteria (Prema, 2013) through antagonist mechanism by inhibiting pathogenic enzyme activities (Ghosh, 2017) and mechanism of nutrient competition (Ferramola, 2013).

Symbiotic microorganisms with plant roots can boost the availability and the absorbance of iron because of its ability to emit siderophore that can bind iron and change it to be dissolved $\mathrm{Fe}^{3+}$ so that it becomes easy to be absorbed by plants (Kraemer, 2003; Ferramola, 2013). Therefore, this study aims to isolate and characterize fungi that can produce siderophore that is potential to be used as biofertilizer and biocontrol for plants.

\section{Materials and Methods}

\section{Fungal Isolates from Rhizosphere}

Fungal isolates were obtained by isolating soil from the rhizosphere area with a dilution of $10^{-4}-10^{-6}$. Then, the isolate was grown in the Potato Dextrose Agar (PDA) medium to get pure isolates.

\section{Siderophore production}

The siderophores produced by fungal isolates were tested using the method by (Reeves, 1983; Sivasakthivelan and Stella, 2012). Media used in this study was the Potato Dextrose Broth (PDB). Three cork borers of fungal isolates were added into each flask and incubated at $37^{\circ} \mathrm{C}$ for 7 days. After 7 day incubation, fungal isolate culture was centrifuged at $10.000 \mathrm{rpm}$ for 2 minutes. Supernatant was used to estimate the salicylate-type siderophore. $20 \mathrm{ml}$ of supernatant culture was taken and the $\mathrm{pH}$ was adjusted to be 2.0 using $\mathrm{HCl}$. After that, 20 $\mathrm{mL}$ of ethyl acetate was added into the supernatant and extracted two times. $5 \mathrm{~mL}$ of tested solution added with $5 \mathrm{~mL}$ of heatway reagent, $1 \mathrm{ml}$ of $0,1 \mathrm{M}$ iron chloride and $1 \mathrm{ml}$ of $0,1 \mathrm{~N} \mathrm{HCl}$ were put into $100 \mathrm{ml}$ of distilled water mixed with $1 \mathrm{ml}$ of $0,1 \mathrm{M}$ Potassium Ferricyanide. Then, the absorbance was measured at $560 \mathrm{~nm}$ using sodium salicylate as the standard to estimate the salicylate-type siderophore.

To measure the concentration of catechol-type siderophore, $5 \mathrm{ml}$ of test solution was mixed with $5 \mathrm{ml}$ Hathway's reagent and the absorbance was set at $700 \mathrm{~nm}$ with 2.3 DHBA as the standard. The concentration of culture filtered was determined and stated in $\mu \mathrm{g}^{-1}$

\section{Identification}

Fungal isolates from rhizosphere were identified macroscopically by observing their colony morphologies including texture, color, reverse color, and radial and concentric lines. The microscopic identification was performed by viewing the hypa, sporangium, conidiophore, and conidia (Watanabe, 2002) at 40x magnification.

\section{Results and Discussion}

Isolation of soil in the rhizosphere area resulted in 10 isolates with various morphological characteristics in the PDA media (Table 1). The color of isolates is predominantly white while reverse colony colors varied (white, yellow, green, and brown) with some different textures e.g. cottony, granular, velvety, and powdery.

The measurement of siderophore concentration showed that those 10 isolates produced various catechol and salicylate siderophore (Graph 1). 
The production of catechol siderophore was between $5,07 \mu \mathrm{g} \mathrm{l}^{-1}$ and $14.87 \mu \mathrm{g} \mathrm{l}^{-1}$ while the salicylate siderophore ranged from $3.89 \mu \mathrm{g} \mathrm{l}^{-1}$ to $7,21 \mu \mathrm{g} \mathrm{l^{-1 }}$. From the graph, it can be seen that ETR 17 isolate released the highest rate of catechol and salicylate siderophore among other isolates which were $14.87 \mu \mathrm{g} \mathrm{l}^{-1}$ and $7.21 \mu \mathrm{g} \mathrm{l}^{-1}$ respectively. The amount of catechol siderophore emitted by ETR17 isolate was higher than the one by the isolate of Sivasakthivelan (2012) which was $8.26 \mu \mathrm{g}$ $1^{-1}$. Meanwhile, salicylatesiderophore was lower than by isolate from Sivasakhthivelan $\left(8.96 \mu \mathrm{g} \mathrm{l}^{-1}\right)$.On the other hand, Kesaulya (2015) identified it to be between $2.772 \mu \mathrm{g} \mathrm{l}^{-1}$ and $4.214 \mu \mathrm{g} \mathrm{l}^{-1}$. This amount is smaller compared with the one produced by ETR 17 .

Table.1 Morphological characteristics of fungal isolates from rhizosphere

\begin{tabular}{llllll}
\hline $\begin{array}{l}\text { Isolate } \\
\text { Shape }\end{array}$ & Texture & $\begin{array}{c}\text { Colony } \\
\text { Colors }\end{array}$ & $\begin{array}{c}\text { Reverse } \\
\text { Colors }\end{array}$ & $\begin{array}{c}\text { Concentris } \\
\text { Lines }\end{array}$ & $\begin{array}{c}\text { Radial } \\
\text { Lines }\end{array}$ \\
\hline ETR5 & Powdery & Green & White & Have & No Have \\
ETR10 & Velvety & White & Brown & Have & No Have \\
ETR11 & Powdery & White & Brown & Have & No Have \\
ETR16 & Granular & Black & White & Have & No Have \\
ETR17 & Granular & Brown & Yellow Have & No Have \\
ETR18 & Granular & Green & White & Have & No Have \\
ETR20 & Cottony & White & White & Have & No Have \\
ETR25 & Velvety & Grey & Yellow No Have & Have \\
ETR26 & Granular & Green & White & Have & No Have \\
ETR29 & Granular & Green & Green & Have & No Have \\
\hline
\end{tabular}

Graph.1 Measurement of catechol and salicylate producing isolates

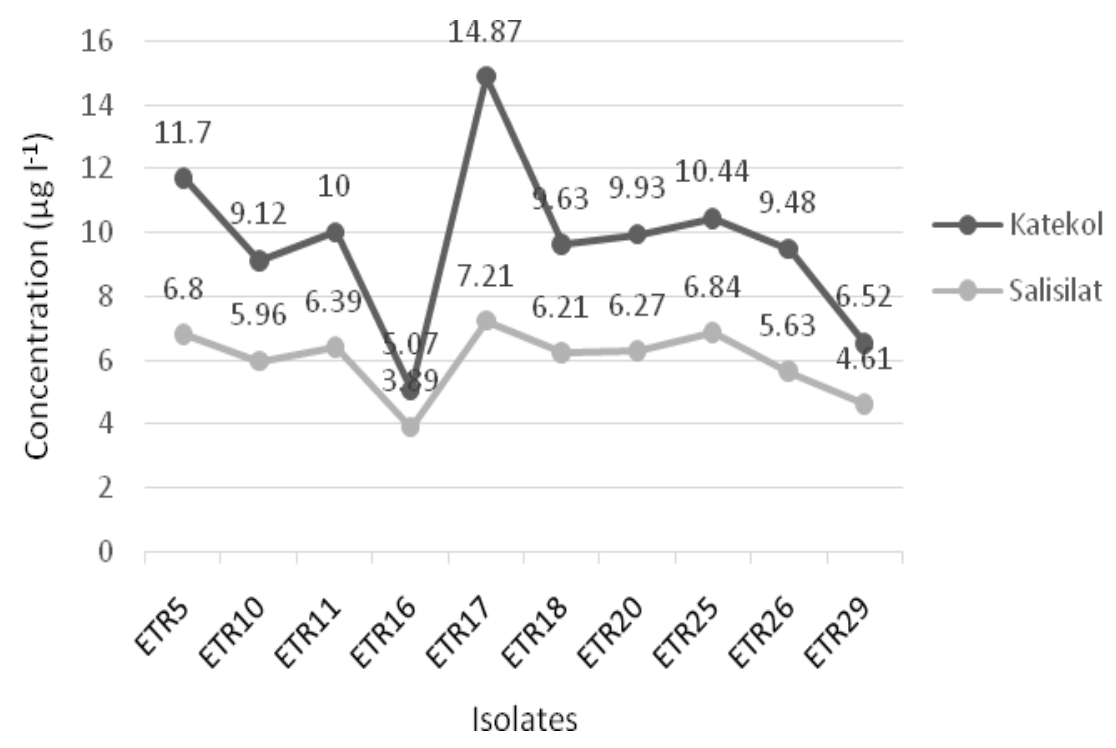


Fig.1 Microscopic of ETR 17 (40x magnification)

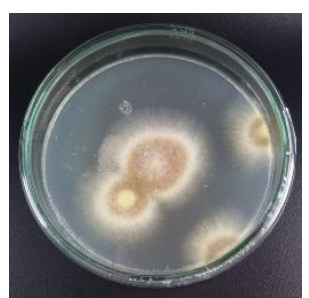

Macroscopically, surface of ETR17 have brown center and white margin of colony culture color. Isolate has granular texture, yellow reverse colony, and concentric line but no radial line. The characteristic of the microscopic isolates is that they have vesicle, phialide, and conidia (Fig. 1). Based on those macroscopic and microscopic features, the type of isolate obtained was Aspergillus sp. This finding confirms the study by Usha (2013) that Aspergillus niger and Aspergillus flavus are two isolates which can secrete high siderophore $\left(12 \mu \mathrm{g} \mathrm{l}^{-1}\right.$ dan $\left.10 \mu \mathrm{g} \mathrm{l}^{-1}\right)$ in black pepper. Therefore, ETR17 isolate can be utilized as biofertilizer and biocontrol to manage fungal phytopathogens.

ETR17 is the isolate that can produce the highest catechol and salicylate siderophore which are $14.87 \mu \mathrm{g} \mathrm{l}^{-1}$ and $7.21 \mu \mathrm{g} \mathrm{l}^{-1}$ respectively. Macroscopic and microscopic observations showed that the type of ETR17 isolate was Aspergillus sp and has the potential to be developed as biofertilizer and biocontrol.

\section{Acknowledgments}

This research was funded by Institute of Fund Management for Education (LPDP) in collaboration with Indonesian Lecturer's Scholarship (BUDI), Ministry of Research, Technology and Higher Education.

\section{References}

Arora, N.K., and Verma, M. (2017). Modified

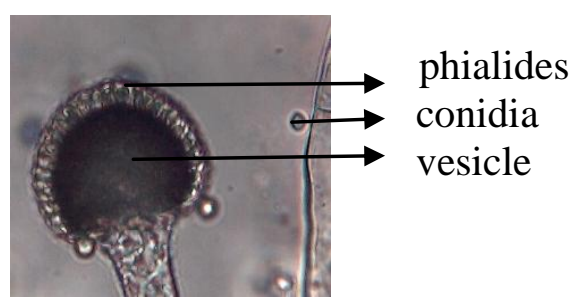

microplate method for rapid and efficient estimation of siderophore produced by bacteria. 3 Biotech 7(381).

Chackraborty, A. et al., (2014). Isolation and characterization of potential plant growth promoting rhizobacteria from non-rhizospheric soil. International Journal of Current Microbiology and Applied Sciences 3(4): 432-438.

Ferramola, M. I. S. et al., (2013). The use of siderophores for improving the control of postharvest diseases in stored fruits and vegetables. Microbial pathogens and strategies for combating them: science, technology and education, Formatex: 1385-1394.

Ghosh,S. K., Pal, S., and Chakraborty, N. (2015). The qualitative and quantitative assay of siderophore production by some microorganisms and effect of different media on its production. Int. J. Chem. Sci, 13(4): 1621-1629.

Ghosh, S.K., Banerjee, S., and Sengupta, C. (2017). Siderophore production by antagonistic fungi: Bioassay, characterization and estimation of siderophores from important antagonistic fungi. J. Biopest, 10(2): 105-112.

Hussein, K.A. and Joo, J.H. (2019). Zinc ions affect siderophore production by fungi isolated from the panax ginseng rhizosphere. J. Microbiol. Biotechnol, 29(1): 105-113.

Kraemer, S.M. (2004). Iron oxide dissolution 
and solubility in the presence of siderophores. Aquatic Science,66: 318.

Kesaulya, H., Baharuddin., Zakaria, B., and Syaiful, S. A. (2015). Isolation and physiological characterization of PGPR from potato plant rhizosphere in medium land of buru island. Procedia Food Science, 3: 190-199.

Miethke, M., and Marahiel, M.A. (2007). Siderophore-based iron acquisition and pathogen control. Microbiology and Molecular Biology Reviews, 71(3): 413-451.

Patil, S., Bheemaraddi, M.C., Shivannavar, C.T., Gaddad, S.M. (2014). Biocontrol activity of siderophore producing Bacillus subtilis CTS-G24 against wilt and dry rot causing fungi in chickpea", IOSR Journal of Agriculture and Veterinary Science, 7(9).

Prema, P., and Selvarani, M. (2013). Microbial siderophore as a potent biocontrol agent for plant pathogens. International Journal of Scientific Research, 2(7): 2277-8179.

Raymond, K. N., Dertz, E. A., and Kim, S. S.
(2003). Enterobactin: an archetype for microbial iron transport, PNAS,100(7): 3584-3588.

Reeves, M.W., Pine, L. Neilands, J.B., and Balows, A. (1983). Absence of Siderophore in Legionella Species Grown in Iron-Deficient Media. Journal of Bacteriology, 154(1): 324329 .

Sivasakthivelan, P., and Stella, D. (2012). Studies on the phytohormone producing potential of agriculturally beneficial microbial (ABM) isolates from different rhizosphere soils of sunflower in Tamil Nadu. International Journal of Pharmaceutical and Biological Archives, 3(5): 1150-1156.

Usha, S., and Padmavathi, T. (2013). Effect of plant growth promoting microorganisms from rhizosphere of Piper ningrum L. International Journal of Pharma and Bio Sciences,4(1): 835846.

Watanabe, T. (2002). Pictorial Atlas of Soil and Seed Fungi Morphologies of Cultured Fungi and Key to Spesies. Florida: CRC Press LLC: 1-486.

\section{How to cite this article:}

Eka Wisdawati, Tutik Kuswinanti, Ade Rosmana and Andi Nasruddin. 2019. Selection and Characterization of Rhizosphere Fungi Producing Siderophore. Int.J.Curr.Microbiol.App.Sci. 8(11): 268-272. doi: https://doi.org/10.20546/ijcmas.2019.811.031 